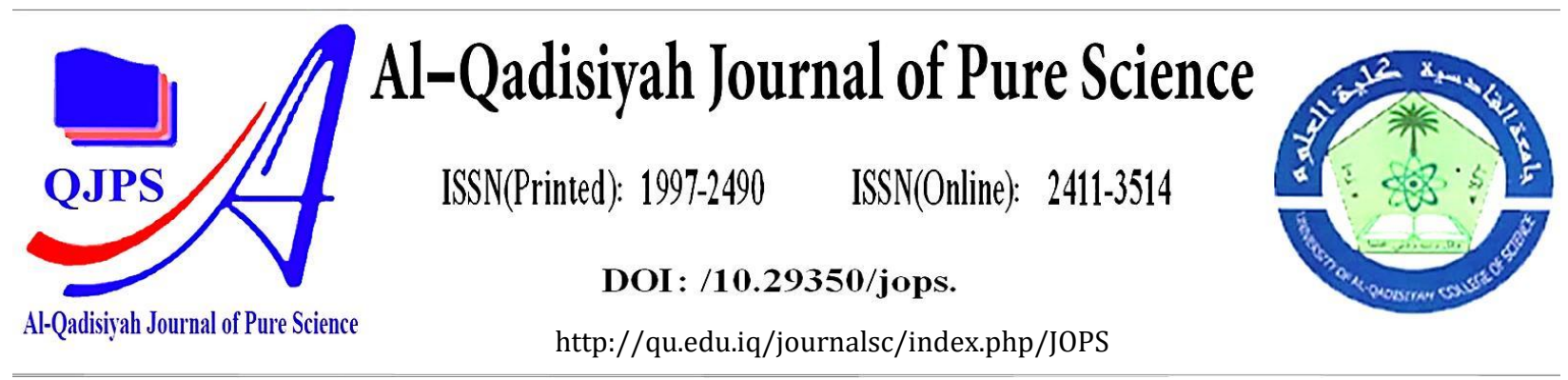

\title{
Studying Cholesterol and Triglyceride Levels in Some Types of Fish
}

\author{
in Salah Al-Din Governorate
}

\section{Authors Names \\ a. Nuha H. Albassam \\ b. Faroq M. Al Habib \\ c. Saddam M. Hassan \\ Article History}

Received on: 29/06/2021

Revised on:11/7/2021

Accepted on: 12/7/2021

\section{Keywords:}

Cholesterol, Triglyceride, Fish, Carasobarbus luteus Alburnus mossulensis

DOI: https://doi.org/10.29350/ jops. 2021.26. 4.1409

\begin{abstract}
The study included seven common types of fish in the Iraqi local market in Salah al-Din Governorate / Tikrit, which are (Carasobarbus luteus, Alburnus mossulensis, Cyprinion kais, Chondrostoma regium, Barbus barbulus, Barbus belayewi, Barbus subquincunciatus). The study of cholesterol and triglycerides of these types of fish showed that the cholesterol levels in the experimental fish were (104.55-9.56 -6.37-9.56 -14.88-51.03-15.94) $\mathrm{mg} / 100 \mathrm{~g}$ in the mentioned fish, respectively, and the highest level of cholesterol was in the Carasobarbus luteus fish and it reached $104.55 \mathrm{mg} / 100 \mathrm{gm}$, and the lowest level in Cyprinion kais is $6.37 \mathrm{mg} / 100 \mathrm{gm}$. The study stated the levels of triglycerides are (990 -348 -993.5 $665.9-703.5-1355.2-882.2$ ) $\mathrm{mg} / \mathrm{kg}$ for fish (Carasobarbus luteus, Alburnus mossulensis, Cyprinion kais, Chondrostoma regium, Barbus barbulus, Barbus belayewi, Barbus subquincunciatus) respectively. The highest level of triglycerides is $1355.2 \mathrm{mg} / \mathrm{kg} . \mathrm{kg}$ in Barbus belayewi fish and the lowest level in Alburnus mossulensis $348 \mathrm{mg} / \mathrm{kg}$.
\end{abstract}

\section{Introduction}

Fish is one of the natural resources that humans have exploited since ancient times. Studies indicate that the human body needs approximately $18 \mathrm{~kg} /$ year of fish, as well as other meat, in order to meet the requirements necessary for health. Therefore, fish is an important component in human diets, and many countries are making great efforts. In order to provide fish as food [11]. It is a well-known fact that the chemical composition of fish is very close to that of other wild animals, and the main components in fish are water (84.66\%), protein (15$25 \%)$, fat $(0.1-24 \%)$ and mineral salts $(0.8-2) \%$ [16].

Several studies were conducted in Iraq, which dealt with the determination of the chemical composition and nutritional value of various Iraqi river and marine fish [1, 10, 3, 13]. [7] studied the chemical composition of fish Tuna in Switzerland, and studied [19] the chemical composition and the proportion of cholesterol and fatty acids. [14] studied the chemical composition of three types of fish as well as the level of cholesterol and calcium of fish fillets. Whereas, [12] studied the level of fatty acids and the proportion of the lipids in the Clupea. In the same year [15] studied the chemical composition, fatty acids, cholesterol and mineral content. 
The current study aims to know the level of cholesterol and triglycerides in seven types of ornamental fish found in Salah El-Din Governorate.

\section{Materials and methods of work}

The experiment was conducted in the Fish Laboratory / Department of Livestock Sciences / College of Agriculture / Tikrit University. Seven types of fish were used (Carasobarbus luteus, Alburnus mossulensis, Cyprinion kais, Chondrostoma regium, Barbus barbulus, Barbus belayewi, Barbus subquincunciatus). The samples were purchased from local markets in Salah al-Din Governorate / Tikrit. Fish weights ranged between (200-950) g, and analyzes were performed on them.

\section{1-Cholesterol Determination}

Determine cholesterol using the method reported by Elias, [9] and developed by [17] and [5]. This method was used to estimate cholesterol in fish by taking $0.1 \mathrm{~g}$ of fresh fish meat and adding $1.9 \mathrm{ml}$ of $95 \%$ ethanol to it. After shaking and centrifuging at $3000 \mathrm{rpm}$ for 15 minutes, 0.5 of the supernatant alcohol was taken into a test tube and $0.25 \mathrm{ml}$ was added to it. From a color reagent such as ferric chloride (prepared by dissolving $0.1 \mathrm{~g}$ of ferric chloride in $100 \mathrm{ml}$ of ethyl acetate) and $2 \mathrm{ml}$ of concentrated sulfuric acid, after shaking and decreasing the temperature of the solution, the optical absorption at a wavelength of $560 \mathrm{~nm}$ is read by a spectrophotometer (APEL type) of Japanese origin in the Department of Livestock Sciences at the University of Tikrit.

\section{*Prepare the Standard Solution}

The imported and ready-made samples were used to prepare the standard solutions, according to the company's instructions, by dissolving $0.02 \mathrm{gm}$ of pure cholesterol in $10 \mathrm{ml}$ of ethanol and transferring $0.5 \mathrm{ml}$ of the last solution, as the above-mentioned steps were performed on it.

\section{*Preparation of the Blank solution}

It is prepared by adding $0.1 \mathrm{ml}$ of distilled water to $1.9 \mathrm{ml}$ of $95 \%$ ethanol and transferring $0.5 \mathrm{ml}$ of the last solution to a test tube and performing the same steps mentioned above.

The amount of cholesterol is extracted from the following equation:

\section{Cholesterol concentration in fish meat $(\mathrm{mg} / \mathrm{g}$ meat $)=$ sample reading / standard cholesterol reading $\mathbf{x} 2$.}

\section{2- Determination of triglycerides: Triglycerides Determination}

For the determination of triglycerides in fish, $0.1 \mathrm{mg}$ of fish meat was used and $2 \mathrm{ml}$ of distilled water was added to it for the purpose of homogenization of the sample.

The tubes were incubated at $37{ }^{\circ} \mathrm{C}$ for 10 minutes, then the absorbance of the samples was read using a Spectrophotometer at a wavelength of $520 \mathrm{~nm}$.

The ratio of triglycerides was calculated according to the following equation: 
Triglyceride concentration $(\mathrm{mg} / \mathrm{g}$ meat $)=$ absorbance of sample / absorbance of standard solution $\mathrm{x} 200$.

\section{Results and discussion}

Table No. (1) states that the highest level of cholesterol was in Carasobarbus luteus $104.55 \mathrm{mg} / 100 \mathrm{~g}$, the lowest level in Cyprinion kais $6.37 \mathrm{mg} / 100 \mathrm{~g}$, and Table No. (1) shows that the cholesterol level in Barbus belayewi is $51.03 \mathrm{mg} / 100 \mathrm{~g}$, which is a result close to the result that reached [4] when estimating the cholesterol in Barbus bynni, which amounted to $59.21 \mathrm{mg} / 100 \mathrm{~g}$, also converged with the results reached by [6], which indicated that the cholesterol in the meat of Atlantic cod was (64-47) mg / $100 \mathrm{~g}$. Respectively, [18] studied the level of cholesterol in the blood serum of common carp fish and noticed a decrease in the cholesterol level of fish fed on rations containing cotton cake with proportions 32.5 and $41 \%$ of the total ration, as cholesterol reached 135 and $140 \mathrm{mg} / 100 \mathrm{~g}$ for fish fed on ration comparison container 30\% soybean meal.

Table (1) Measurements of cholesterol and triglycerides in experimental fish

\begin{tabular}{|c|c|}
\hline Triglycerides (mg/g meat) & Fish type \\
\hline $0.23 \pm 104.55$ & Carasobarbus luteus \\
\hline $1.22 \pm 9.56$ & Alburnus mossulensis \\
\hline $0.86 \pm 6.37$ & Cyprinion kais \\
\hline $1.09 \pm 9.56$ & Chondrostoma regium \\
\hline $0.98 \pm 14.88$ & Barbus barbulus \\
\hline $0.24 \pm 51.03$ & Barbus belayewi \\
\hline $1.20 \pm 15.94$ & Barbus subquincunciatus \\
\hline
\end{tabular}

Table No. (2) states the level of triglycerides in the seven experimental fish, and the highest level was in Barbus belayewi $1355.29 \mathrm{mg} / \mathrm{kg}$, and the lowest level of triglycerides in quail fish was $348 \mathrm{mg} / \mathrm{kg}$. When estimating the triglycerides in the Barbus belayewi, [2] reached a quantity of 725.66 triglycerides. [8] mentioned that the presence of dietary fiber and pectin in diets inhibits the absorption of triglycerides in the intestine, and this leads to a decrease in the level of cholesterol entering the hepatic circulation and thus a decrease in its concentration in the blood. Most studies also indicate that the Barbus belayewi begins to breed at the end of the spring, and this may be the reason for the high percentage of fat in winter, and Alburnus mossulensis recorded the lowest triglycerides, reaching 348. 
Table No. (2) The amount of triglycerides in the meat of the experimental fish

\begin{tabular}{|c|c|}
\hline Triglycerides (mg/g meat) & Carasobarbus luteus \\
\hline $1.31 \pm 990$ & Alburnus mossulensis \\
\hline $1.22 \pm 348$ & Cyprinion kais \\
\hline $1.07 \pm 993.5$ & Chondrostoma regium \\
\hline $0.98 \pm 665.9$ & Barbus barbulus \\
\hline $1.25 \pm 703.5$ & Barbus belayewi \\
\hline $1.57 \pm 1355.29$ & Barbus subquincunciatus \\
\hline $0.95 \pm 882.25$ & Carasobarbus luteus \\
\hline
\end{tabular}

\section{References}

[1]AL-Aswad, M.B., A.J. Abo-Elnaga and N.H. Ahmad (1980). Chemical and bacteria on some commercially important fish in Dukan lake II. The natural bacteria flora, Zanko, 6(4):29-36.

[2]Al-Bishr, Wael Assem Khalaf (2012). Determination of Triglycerides and Cholesterol in Some Economical Fish Oils in Salah Al-Din Governorate. Master's Thesis, College of Agriculture. Tikrit University: 60 pages.

[3]Al-Fadhli, Nawal Khaled Zebein (2009). Salting and drying of rib fish Scomberoides commersonianus and study of its qualitative characteristics using sensory, chemical, physical and microbial evidence. Master Thesis, College of Agriculture, University of Basra. 127 pages.

[4]Al-Jubouri, Duraid Hamada Ayyash (2009). Effect of cooking methods on the chemical composition and nutritional value of the meat of some Iraqi local fish. Master's thesis, College of Agriculture, Tikrit University: 102 pages.

[5]Al-Jumaily, Tariq Khalaf Hussein (2004). Effect of feeding quail females on different sources of oils and fats on productive performance, egg yolk and blood serum content of fatty acids and cholesterol, Master's thesis, College of Agriculture. Tikrit University: 71 pages.

[6]Archuleta, M (2003). Fitting Meat, poultry and fish into a healthy Diet. Guide-E. 129. New Mexico state University, 1-4 page.

[7]Avarani, M (2004). Application of NIR spectroscopy in the determination of chemical composition of thawed precooked tuna fillets. University degli study Milano, Milan, Italy, 37:4 page.

[8]Cara,L.;C.Dobis;P. Borel; M. Senft; H.Portungal;A.M. Pauli; P.M.Bernard;D.Lairon (1992). Effect of oat bran, Rice bran, wheat fiber and germ on postprandial (Lipidemia in Health Adult). Am.J.clin.Nutr. 55: 81-88.

[9]Francy, R.T. and A.Elias (1986). Serum cholesterol measurement based on ethanol extraction and ferric chloride sulfuric acid. Clin.

[10]Habib, Farouk Mahmoud Kamel (2001). Presence of Carassius Carassius fish in Iraqi internal waters. Tikrit University Journal of Agricultural Sciences. (2): 103-114.

[11]Hassan, Bassem Jumaa Al-Qaddo and Mahmoud Radi Hassan (1981). The economics of fisheries wealth in the Arab world. Fisheries Magazine. The second issue 5-22 pages. 
[12]Huynh, M.D.,D.D.Kihs, C Huand A.W. Trites (2007). Comparison of fatty acid profiles of spawning and nonspawning pacific herring Clupea harengus pallasi. Comparative biochemistry and physiology.

[13]Khader, Zaid Khalaf (2011). Comparison of the evaluation of the quality of five types of local fresh fish in the markets of Sulaymaniyah Governorate. PhD thesis, College of Veterinary Medicine, University of Sulaymaniyah. 171 pages.

[14]Krzynowek, A. and Mehmet, C (2006). Amino acid composition of blue carp (callinectes sapidas) from the north Eastern Meditrcanean Sea. J.of APPI. Biological science.

[15]Meimaroglou. SM, C.Dimizas, V.Loukas, A.MOUKAS, A.Vlachos, N.Thomaidis, V.Paraskevopoulou and M.Dasenakis (2007). Proximate composition, fatty acid, cholesterol, minerals in frozen red porgy. Chemistry and physic of lipids.

[16]Muhammad, Mustafa Safwat, Muhammad Fahmy Hussein and Yahya Muhammad Hussein (1967). fish technology. First edition, Dar Al Maaref, Egypt, Cairo. 569 pages.

[17]Nagy, Saad Abdel-Hassan (1977). Effect of using different sheds and rearing systems on productive efficiency and egg quality, as well as on cholesterol in the blood and egg yolk of laying hens, Master's thesis, College of Agriculture, College of Agriculture. University of Baghdad 87 pages.

[18]Salh Yi, Vian Salih Muhammed (2006). The effect of substituting cottonseed cake for soybean meal on the diets of common carp Cyprinus carpio L. common carp. Master Thesis, College of Agriculture, University of Salah al-Din: p.77.

[19]Tarly. C.R.T., J.V. Visentainer, Matsushita and N.E.Souza (2004). Proximate composition, cholesterol of fatty acid profiles of canned sardine sardinella brasiliensis in soybean oil and tomato sauce. Food chemistry. 